\title{
English Loanwords in the Destinasi Indonesia Magazine (Kata Serapan Bahasa Inggris dalam Majalah Destinasi Indonesia)
}

\author{
Apriana Nugraeni ${ }^{a, 1}$ dan Teguh Setiawan ${ }^{a, 2}$ \\ ${ }^{a}$ Department of Applied Linguistics, Yogyakarta State University, Yogyakarta, Indonesia \\ ${ }^{1}$ myname.apriana@gmail.com; ${ }^{2}$ teguh_setiawan@uny.ac.id
}

\begin{tabular}{ll}
\hline Article info & A B S T R A C T \\
\hline Article history: & This research to describe English loanwords in the Destinasi \\
Revised : 29-01-2020 2020 & Indonesia printed magazine, which focuses on travel, tourism \\
Accepted: 11-03-2021 & destination guidance, and culinary. It focuses on several \\
types, strategies, and equivalences of form, pronunciation, & and meaning of those languages. The research used \\
& qualitative content analysis on a written document. The \\
& results show that types of English loanwords in Indonesian \\
& are in the form of words and phrases. The strategies are \\
& adoption, adaptation, translation, and creation. In the \\
& adoption strategy, the researchers invented partial and full \\
& adoption. They also discovered terms with the same form and \\
& meaning but distinct pronunciation in equivalences of form, \\
& pronunciation, and meaning. The pronunciation and meaning \\
& are the same, but the form is different. The concept is the \\
& same, but the form and pronunciation are different, or the \\
& points are the same as a whole. These English loanwords have \\
profoundly modernized Indonesian lexicons.
\end{tabular}

Keywords:

Destinasi Indonesia loadwords English modernized Indonesian lexicons

tourism magazine
Penelitian ini bertujuan untuk mendeskripsikan kata serapan Bahasa Inggris dalam majalah Destinasi Indonesia yang membahas perjalanan, panduan destinasi wisata, dan kuliner. Penelitian berfokus pada tipe unsur serapan, strategi, serta kesejajaran bentuk, lafal, dan makna antara kedua bahasa. Penelitian menggunakan pendekatan kualitatif analisis isi pada dokumen tertulis. Hasil penelitian menunjukkan tipe unsur serapan Bahasa Inggris dalam Bahasa Indonesia adalah kata dan frasa. Strateginya adalah adopsi, adaptasi, terjemahan, dan kreasi. Dalam strategi adopsi, ditemukan adopsi sebagian dan penuh. Pada kesejajaran bentuk, lafal, dan makna, ditemukan kata yang memiliki bentuk dan makna sejajar, lafal berbeda. Lafal dan makna sejajar, bentuk berbeda. Makna sejajar, bentuk dan lafal berbeda atau sejajar secara keseluruhan. Kata serapan Bahasa Inggris memodernisasi leksikon dalam Bahasa Indonesia.

Copyright $\odot 2021$ Institut Agama Islam Negeri Syekh Nurjati Cirebon. All rights reserved.

\section{INTRODUCTION}

Language does not exist in isolation, but it is constantly in interaction with other languages. Borrowings alter linguistic systems in language contact situations (Mihalicek \& Wilson, 2011). One language tends to integrate with others as a result of this contact. English has a hegemony over the world language and dominates international politics. It also applies to Indonesian, which assimilates other languages, such as English (Murtisari \& Mali, 2017). According to 
Moehkardi (2019), English has an influence on Indonesian lexical terms (Mulyaningsih, 2017). Furthermore, Indonesians continue to use it as a language of access, notably in the fields of technology and science, to this very day. Furthermore, from a historical point of view, the British colonized Indonesia in the 18th century before returning to the Dutch. Frederick and Worden (2017) argue that the British assumed control of the Dutch administration in Indonesia from 1811 to 1816 , led by liberal reformer Thomas Stanford Raffles. Before creating Singapore, the British had an agreement with the Dutch to colonize Indonesia. However, English is not an official language in Indonesia because it is spoken as a foreign language by the government and public servants. Because Indonesia is not a British or American colony, there is no precedent for using English in government or everyday communication (Lauder, 2008).

Samuel (2008) emphasizes that English is only used in Indonesian education if it has been taught in teaching-learning processes since 1967 at the junior and senior high school levels. In these approaches, English was taught through texts and books rather than classroom conversations. Carr (1958) adds that Indonesians prepared to incorporate foreign sounds into its phonemic system, foreign words into its lexical system, and foreign word order into its syntactical system after becoming newly sovereign. Foreign affixes such as anti-, -isme, and others have been adapted and have begun to be productive from English to Indonesian. In addition, Sneddon in Tabiati and Yanuar (2012) points out that Indonesian media have overexposed their readers to many English words. They have identified substantial borrowings or loanwords since 1966.

The language that is borrowed is known as recipient language, and the language that is given is known as donor language. Some indicators of borrowing, according to Khaled (2013), are assimilated words into the recipient language. As a monolingual, foreign words are borrowed and merged into one's native language, resulting in attitudes for daily communication and a verbal repertoire. They were all found in the official Kamus Besar Bahasa Indonesia (KBBI), with some of them altered to the phonological system. It is bolstered by Crystal in Marmiéné (2015), who claims that borrowing exists but never returns in the sense of reciprocity.

The magazine focuses on more specialized readers who are more likely to use specific terms. In a nutshell, Destinasi Indonesia is an Indonesian monthly magazine that concentrates on traveling, tourism destination guides, and culinary information from all across the country. Culinary, travel, and a variety of unique tourism goods have all seen significant growth in recent years. According to Ramadhita (2013), Indonesia currently offers several exotic tourism destinations of outstanding natural beauty, historical heritage sites, and traditional cultures that fascinate many people. The magazine is chosen because it contains English borrowings. For example, the word spot is borrowed from English. There is also swafoto, which is a selfie translated from English; tur, which is a tour translated from English, and so on. All of them modernize Indonesian lexicons.

Winarto (2009) examined borrowing words in the Newspaper Seputar Indonesia Decsember 2009, which set this article apart from previous studies. He only analyzed specific articles based on borrowing words like education, entertainment, sport, science, technology, hobbies, lifestyle, politics, and international news. In his research, he found terms of borrowing words that identified from changing of meaning as extension, narrowing, and synonym based 
on strategies of borrowing of Haugen theory like loanblend, loanword especially duel, mode, model, and target. Supeni \& Fauziah (2018) analyzed English Loanwords on Indonesian Health Article in Online News Pages. They examined English loanwords in Indonesian articles on websites like Detik.com, Kompas.com, and Vivanews.com. They looked for loanwords in Indonesian that were morphological and phonological and based on word categories such as noun, verb, adjective, and adverb. In their research, they classified loanwords based on morphological processes like as reduplication and abbreviation. They discovered loanwords in three ways while studying the phonological process: adoption, adaptation, and translation.

This article aims to investigate English loanwords in Indonesian, with a focus on the sorts of English borrowing words in Indonesian, assimilation strategies in Indonesian, and form, pronunciation, and meaning equivalences between English and Indonesian in the magazine.

\section{METHOD}

This research is a descriptive qualitative study that uses content analysis to examine all pages of the Destinasi Indonesia magazine from May to September 2019. It took only five months to complete. The data on English borrowing words in the text was collected using the observation method. Simak and catat techniques are included in this method. According to Sudaryanto (2015), the goals of metode simak and teknik catat are to record all data and write everything down in the field note. The first stage is to observe, which entails reviewing the entire data source and taking meticulous notes. The field note is given through a table as a data card that was arranged to answer research problems in the second step. The research instrument is a human instrument based on borrowing indicators: (1) English lexicons that have assimilated to Indonesian, (2) English lexicons discovered in KBBI, and (3) English lexicons that have changed form, pronunciation, or meaning in Indonesian.

This study used a purposive sampling technique to select a sample based on a set of criteria, including indicators of borrowing that suited the scope of the study and also provided answers to the research questions. More specifically, homogeneous sampling was used to ensure that all borrowing items selected had similar treats. The triangulation theory and data source were utilized to determine the data's trustworthiness. The padan translasional method and interlingual technique were utilized to analyze the data. Sudaryanto (2015) states that the translational approach is utilized to define terms by measuring different languages as a research parameter. On the other hand, it used syntactical and semantic analysis to anchor the data in the real world, which could not really separate from the two languages searched. It used the most recent update of the Cambridge online dictionary to closely match form, pronunciation, and meaning. (https://dictionary.cambridge.org/online/ and online Kamus Bahasa Indonesia (https://kbbi.kemdikbud.go.id/).

\section{RESULTS AND DISCUSSION}

Following a thorough analysis, the Destinasi Indonesia magazine discovered 250 borrowing items. In the form of a phrase, there was also evidence of English borrowing in Indonesian. As a result, 229 words and 21 phrases were identified in 
total. Adoption, adaptation, translation, and creation are the four categories of English borrowing strategies in Indonesian. There were 21 terms and 0 phrases found in total utilizing the adoption strategy. There are 206 words and 17 phrases borrowed using the adaptation strategy. 2 words and 1 sentence are borrowed using the translation strategy. Borrowing with the creation strategy is 3 phrases, 0 words, and 0 terms. There are a total of 250 items available for borrowings. Detail information is provided in table 1 .

Table 1.

Frequences of Types and Strategies of English Borrowings in Indonesian

\begin{tabular}{|c|c|c|c|c|c|c|}
\hline \multirow{2}{*}{ No. } & \multirow{2}{*}{$\begin{array}{c}\text { Types of } \\
\text { Borrowing }\end{array}$} & \multicolumn{4}{|c|}{ Strategies of Borrowing } & \multirow{2}{*}{ Total } \\
\hline & & Adoption & Adaptation & Translation & Creation & \\
\hline 1 & Word & 21 & 206 & 2 & 0 & 229 \\
\hline 2 & Phrase & 0 & 17 & 1 & 3 & 21 \\
\hline & Total & 21 & 223 & 3 & 3 & 250 \\
\hline
\end{tabular}

\section{Types of English Borrowings in Indonesian}

According to Haugen (1950), there are two types of borrowings in English: word and phrase borrowings. Basic word, compound word, derivative word, acronym, self-name, reduplication, and word category are the seven groups of words. The following are some examples of data from table 2. For annotation, $\mathrm{DL}=$ donor language, $\mathrm{RL}=$ recipient language, -------- = same type/sentence/source.

\section{Word}

Word, according to KBBI online (2019), is the smallest meaningful element used to speak or write, and it can be used to form phrases, clauses, and sentences, all of which are separated by space. It is commonly referred to as general lexicons. Pearson in Khan (2016) defines a word as the smallest linguistic unit that conveys a distinct meaning and is separated in a sentence by spaces and punctuation before and after it. The data designate that there are 229 items of English borrowing in Indonesian in the form of terms that are split into several groupings. The following are some examples based on sentences from the magazine.

\section{Basic word}

In the data studied, there are two examples of basic words found in Selain sesi yoga, adapula kelas memasak dan penampilan musik (Juli, 2019). Sesi is a loanword from the English word session. Because it does not go through affixation, reduplication, or compounding, it is referred to as a basic word. It was once used as a foundation to form words on a wider scale. Basic words, according to Hymes in Tadmor et al. (2010), are seen as lexical resistance borrowing and are widely used for possible communication from a variety of words. They may be applicable to a thousand different languages. In the same line, the basic word kelas, which comes from the English word class, and musik, which comes from the English word music, may be discovered. 
Table 2.

Examples of data related to types of English borrowings in Indonesian

No. Data

(RL)
Sentences

Selain sesi yoga, adapula kelas memasak dan penampilan musik.

2. Kelas Class

3. Musik Music

4. Mengidentifi Identify kasi

5. Arung jeram Rafting Phrase

6. Humas

7. Polandia

Poland

Public relation

Word

8. Butik- butik

Boutiques
9. Museum
Museum
10. Arsitektur
Achitecture
11. Kuliner
Culinary
12. Desain
Design untuk deluxe room kapasitas 2 orang.

Amati ular yang ditemui dan segera mengidentifikasi jenis ular dengan ciri-cirinya yang kasat mata.
Museum, tugu peringatan, arsitektur khas, kuliner, keberadaan butik-butik menjadi sasaran yang sulit diabaikan.

Selain kegiatan tahunan, komunitas ini juga mengadakan kegiatan harian yang dilakukan oleh para penggiatnya seperti bersih-bersih bantaran sungai, menanam pohon, serta permainan arung jeram.

Manager Humas Grand Candi, Azkar Rizal Muhammad menyebutkan, salah satu promo menarik untuk kalangan muda, yakni Weekend Rate dengan harga Rp 655.000 Nett/ Room/ Night

Ibu kota Polandia ini menjadi salah satu kota yang banyak dicari di Culture Trip.

Mei, 2019

Mei, 2019

Pendaftaran Modest Young Designer Competition yang mengusung acara desain "Neo Medieval" atau "Exhuberant", telah berlangsung sebulan lalu.

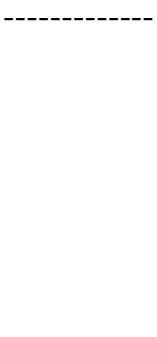

Juli, 2019

Agustus, 2019 Agustus, 2019

\section{9}




\section{Derivative Word}

Mengidentifikasi is derived from the basic term identifikasi, which is borrowed from English and is classified as a verb, as shown in Amati ular yang ditemui dan segera mengidentifikasi jenis ular dengan ciri-cirinya yang kasat mata (Agustus, 2019). In Indonesian, the term identifikasi is derived from identification and becomes mengidentifikasi, which goes through a grammatical process and changes its word category from noun to verb by receiving the affixation me-kan, which is a derivative word. A derivative term is one that has been totally borrowed into Indonesian and has been transformed by affixes such as prefixes and suffixes. Cholsy et al. (2014) outline that the prefix meng- has the status of a word integration because affixation is one of Indonesian words' structural characteristics. Initially, the derivative word mengidentifikasi had the prefix me-followed by the vowel $i$ and was morphophonemically transformed to meng-. Borrowing nouns and adjectives, according to Stene Haugen in Wohlgemuth (2009), can be used in sentence construction and do not need to be inflected, although verbs cannot.

\section{Compound Word}

In the sentence Selain kegiatan tahunan, komunitas ini juga mengadakan kegiatan harian yang dilakukan oleh para penggiatnya seperti bersih-bersih bantaran sungai, menanam pohon, serta permainan arung jeram (Agustus, 2019), the words arung jeram are an attempt to translate English into Indonesian. It is actually a compound term in Indonesian, with the words arung and jeram generating new meanings, although they cannot be used backwards as jeram arung meaning. As a result, complex words are grouped to words, however, they are derived from English, with rafting becoming arung jeram in Indonesian. Because it has more than one word in its pattern, it is rephrased as grammatical. Bauer in Moehkardi (2016) argues that compound refers to the transformation of two words into new ones. It is a process in which at least two free morphemes are combined to generate a new structure with new meaning.

\section{Acronym}

In the sentence Manager Humas Grand Candi, Azkar Rizal Muhammad menyebutkan, salah satu promo menarik untuk kalangan muda, yakni Weekend Rate dengan harga Rp 655.000 Nett/ Room/ Night untuk deluxe room kapasitas 2 orang (Agustus, 2019), the word Humas is a shorter form of the Indonesian phrase Hubungan Masyarakat. It is derived from the English word public relation, which goes through a translation process. The shorter form of Hubungan Masyarakat is humas, which goes through morphological changes and belongs to the abbreviation branch of acronyms, which is a word or phrase that is shortened and strives to reflect the whole. Susetyo (2016) conducted the same research and categorized words into five groups: basic words, derivative words, compound words, and acronyms.

\section{Self-name}

In the sentence Ibu Kota Polandia ini menjadi salah satu kota yang banyak dicari di Culture Trip (Mei, 2019), Polandia is a country name derived from the English word Poland. The self-name, which describes the names of persons, places, months, days, and religious days that may be matched to the local culture of where people reside, can also be used to identify different types of borrowing. The name of the country is the same as the name of the person. Valtonen (2017) conducted a similar study, looking into borrowing place names that refer to the 
same concept of naturally starting contact without conflict. When two cultures and languages contact, borrowing, such as language adaptation, is a simple approach to be reflected in a position where the minority group can peacefully coexist with the majority group in a language contact situation. Addressing the meaning of place names, according to Helleland (2012), may express feelings of individual and collective identity. Its goal is to name a place after another place with a similar name, using cognitive linguistics, anthropology, and history as guides.

\section{Reduplication}

In the sentence Museum, tugu peringatan, arsitektur khas, kuliner, keberadaan butik-butik menjadi sasaran yang sulit diabaikan (Mei, 2019), butikbutik is an English word that means "boutique." The syllables butik-butik appear to be repeated throughout the text, but they are actually borrowed as boutique. According to Katamba in Nian et al. (2012), reduplication is defined as the repetition of all elements and could be a radical element. Reduplication occurs in this case once they are borrowed in Indonesian. Nian et al. (2012) conducted a similar study in Malay and Japanese, looking into full reduplication. It is discussed in terms of the outcomes of its reduplication to state lexical function in both languages, with an explanation in English at the end. Apart from the reduplication butik-butik, the sentence also contains basic words such as museum borrowed from museum, arsitektur borrowed from architecture, and kuliner taken from culinary.

From such cases, Darheni (2009) discovered three different ways of borrowing foreign words into Indonesian morphologically. Affixation, reduplication, and abbreviation are the three terms for them. A borrowed word from English, mengharmonisasi, is used in affixation. There are two things that have been explained in this case. To begin, the term harmonize requires the prefix me- to become meng-harmonisasi = mengharmonisasi, because it has been converted to Indonesian. Second, in terms of word order, harmonize is a verb, while harmonization is a noun in Indonesian. Prefixes are always followed by verbs, and affixations like ber-, di-, and ter- are used on nouns like bernuansa, didesain, and terkontrol. These formations are based on the context of the sentence. There are words butik-butik borrowed from English, boutiques, in reduplication. The suffix $-\mathrm{s}$ in the word boutiques indicates that there are more than one boutiques in the plural, which is referred to as reduplication. For example, a word borrowed from English such as media sosial, means "social media" in abbreviation. It has a noun phrase pattern that is abbreviated as medsos.

\section{Word Category}

In the sentence Pendaftaran Modest Young Designer Competition yang mengusung acara desain "Neo Medieval" atau "Exhuberant", telah berlangsung sebulan lalu (Mei, 2019), desain is an English word that means design. The context of the statement suggests that desain is a noun, but it is actually a verb. In fact, when borrowing words from English to Indonesian, there is a change in word category. Auer (2014) conducted the same research and believes that kind of borrowing can be dependent on word categories. They are broken down into seven categories: verb, noun, adjective, adverbial, number, pronoun, and particle (which includes preposition, conjunction, interjection, and article). At some point, the word category changes. Haugen in Wohgelmuth (2009) states that apart from phonological adaptation, there is grammatical accommodation of borrowing words, notably part of speech allocations. He created a scale of adoptability based 

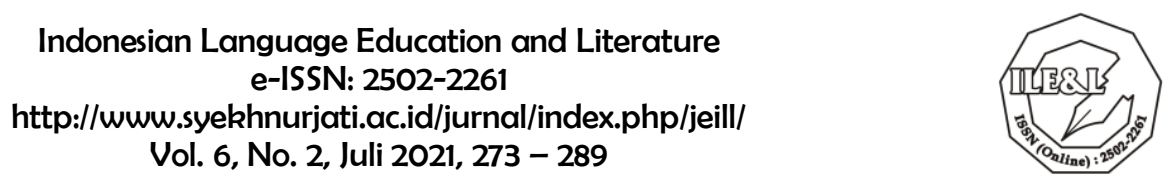

on this premise. Nouns > verbs > adjectives > adverbs and prepositions > interjections are the order of precedence. It demonstrates that verbs have a lower borrowing possibility than nouns.

Phrase

A total of 21 items were discovered to be borrowed in the type of phrase. The following are some examples based on the sentences. Kosmetik ini menjadi simbol tradisi kedewasaan wanita melalui fesyen dan beauty (Juni, 2019). Tradition symbol, which symbol to be the core in an aspect of this structure, is a phrase taken from English. Tradition symbol in English refers to a symbol that modifies a tradition whose main part is a noun. This phrase also goes through phonological adaptation, with some phonemes changing according to Indonesian rules. Unlike a clause or a sentence, a phrase is a group of words that are used together and have a specific meaning. However, unlike a clause or a sentence, a phrase does not contain a subject or a verb. Haugen (1950) highlights that foreign words borrowed must be accommodated to the grammatical structure of the receiving language without changing parts of speech. It solely changes in terms of grammar. For example, the class of nouns is still nouns, and so on. Meridhita (2012) describes that one of the hallmarks of borrowing is donor language, which releases its element without influencing the structure of the recipient language. It means that the structure of borrowed words in the recipient language can change, but not the word category.

In the sentence "Saya belum pernah menemukan di dunia ini, kehidupan seinteraktif dan harmonisasi sosial seindah di Lasem” (Agustus, 2019), The phrase harmonisasi sosial, or social harmonization, is taken from English. In one element of this constituent, the term harmonisasi becomes a core. It is a nounphrase in which the noun harmonization modifies the adjective social. According to Aarts and Haegeman (2006), the term relates to the extension or projection of words. Both form and meaning are grouped into a string as unit/constituent. It is not the same with idiomatic expressions or denotative meaning.

\section{Strategies of English Borrowing in Indonesian}

There are several ways for assimilation of English into Indonesian, including adoption, adaptation, translation, and creation (Moeliono, 1985). Table 3 contains examples of data as well as concise explanations of the data. For annotation, --------- = same strategies/ sentence/ source.

\section{Adoption}

Adoption is a strategy in which a user adopts a new foreign word as its original pattern. According to the findings, borrowing words utilizing the adoption technique resulted in 21 words and 0 phrases. Some examples are based on the sentences listed below. In the sentence Bisa didapat menu aneka snack, menu breakfast, spageti, chicken porridge, burger, dan masih banyak lagi (Mei, 2019), the word burger is derived from the English word burger, which was originally used as a pattern. It is the same as Indonesian in terms of orthography, but it is pronounced differently. Burger is pronounced $/{ }^{\prime} b 3 . . g \partial^{r} /$ in English. As a result, the scholars assert that it becomes a case of incomplete adoption. The term "burger" was chosen to represent a name for an object that has no Indonesian equivalent.

In the sentence Film sangat berperan sebagai media propaganda dan promosi, apalagi untuk pariwisata (Mei, 2019), the term film is likewise drawn from English and utilized as an original pattern, but its form, meaning, and pronunciation remain unchanged. Hence, the researchers concluded that full- 
adoption is the correct phrase. Film is pronounced / film/ in English, and the same is true in Indonesian as the recipient language. Though the vowels in the English phoneme $i$ vary, it sounds like $/ i$ / in Indonesian.

Table 3.

Examples of data related to strategies of English borrowing words in Indonesian

\begin{tabular}{|c|c|c|c|c|c|}
\hline No. & $\begin{array}{l}\text { Data } \\
\text { (DL) }\end{array}$ & $\begin{array}{l}\text { Data } \\
\text { (RL) }\end{array}$ & Strategies & Sentences & Sources \\
\hline 1. & Burger & Burger & Adoption & $\begin{array}{l}\text { Bisa didapat menu aneka } \\
\text { snack, menu breakfast, } \\
\text { spageti, chicken porridge, } \\
\text { burger, dan masih banyak } \\
\text { lagi. }\end{array}$ & Mei, 2019 \\
\hline 2. & Film & Film & ------------- & $\begin{array}{l}\text { Film sangat berperan sebagai } \\
\text { media propaganda dan } \\
\text { promosi, apalagi untuk } \\
\text { pariwisata. }\end{array}$ & ------------- \\
\hline 3. & Bestik & $\begin{array}{l}\text { Beef } \\
\text { steak }\end{array}$ & Adaptation & $\begin{array}{l}\text { Bestik sapi dan bestik lidah } \\
\text { merupakan menu kuno yang } \\
\text { masih menjadi favorit } \\
\text { pengunjung hingga saat ini. }\end{array}$ & Juli, 2019 \\
\hline 4. & Kolonial & Colonial & ------------- & $\begin{array}{l}\text { Bangunan-bangunan kolonial } \\
\text { yang indah dan berwarna- } \\
\text { warni, balkon penuh bunga, } \\
\text { gereja dengan arsitektur yang } \\
\text { indah, menjadikan Cartagena } \\
\text { salah satu situs warisan dunia } \\
\text { Unesco. }\end{array}$ & Mei, 2019 \\
\hline 5. & Balkon & Balcon & ----- & -------------------- & ------------- \\
\hline 6. & $\begin{array}{l}\text { Arsitektu } \\
r\end{array}$ & $\begin{array}{l}\text { Architect } \\
\text { ure }\end{array}$ & ----- & & ------ \\
\hline 7. & Situs & Site & ------------ & -------------------- & ------------- \\
\hline 8 & $\begin{array}{l}\text { Harmoni } \\
\text { sasi } \\
\text { sosial }\end{array}$ & $\begin{array}{l}\text { Social } \\
\text { harmoniz } \\
\text { ation }\end{array}$ & ------------- & $\begin{array}{l}\text { "Saya belum pernah } \\
\text { menemukan di dunia ini, } \\
\text { kehidupan seinteraktif dan } \\
\text { harmonisasi sosial seindah di } \\
\text { Lasem," katanya. }\end{array}$ & Agustus, 2019 \\
\hline 9. & Swafoto & Selfie & Translation & $\begin{array}{l}\text { Jangan lewatkan swafoto di } \\
\text { spot-spot cantik dan unik yang } \\
\text { telah disediakan. }\end{array}$ & ------------- \\
\hline 10. & $\begin{array}{l}\text { Nota } \\
\text { kesepaha } \\
\text { man }\end{array}$ & $\begin{array}{l}\text { Memora } \\
\text { ndum of } \\
\text { understa } \\
\text { nding }\end{array}$ & --------------' & $\begin{array}{l}\text { Penandatanganan nota } \\
\text { kesepahaman antara } \\
\text { Traveloka dan Japan Railway } \\
\text { Company, dilakukan di } \\
\text { Jakarta. }\end{array}$ & Juli, 2019 \\
\hline
\end{tabular}


Borrowing has a different adoption strategy than code switching. The difference between code switching and borrowing, according to Hudson in Khaled (2013), is that borrowing words from one language to be part of another language links its own mixing system. It signifies that borrowing words have become integrated into one's own monolingual language. Meanwhile, code switching inserts another language at the level of clause, and because the other language utilized in this insertion may not have merged into the own language, it is not classified as monolingual. Monolingual words are all those found in KBBI. In Indonesia, not all English lexicons are borrowed. Borrowing, according to Haugen (1950), refers to speakers who unconsciously incorporate components of a second language into their own, and there is no obligation to repay the loans.

\section{Adaptation}

Adaptation is a strategy in which a user learns a new foreign word but adapts the pronunciation to the Indonesian recipient language. Susetyo (2016) emphasizes that adaptation is the result of a language contact scenario between people who influence each other. People interact with one another, and language absorption occurs. There are language units and language structures that are open to the influence and those that are close to it. Open refers to how simple it is for a speaker to pick up on the impact of another language, whereas close refers to how difficult it is for a speaker to pick up on it. Haugen (1950) adds that adaptation is a slip in part of every native morpheme for certain components of the foreign. The findings show that on the basis of phonological form, a scale for borrowing time can be created. Borrowing that used an adaptation strategy resulted in 206 words and 17 phrases. The following are some examples based on sentences.

The word bestik is adopted from English, as seen in the sentence Bestik sapi dan bestik lidah merupakan menu kuno yang masih menjadi favorit pengunjung hingga saat ini (July, 2019). It is Indonesian-adapted and undergoes morphological changes to become bestik. Rahman (2018) conducted a similar investigation into colonial heritage foods and their history in Indonesia, which has been nationalized and has become a national identity.

Furthermore, several adapting words may be found in the sentence Bangunan-bangunan kolonial yang indah dan berwarna-warni, balkon penuh bunga, gereja dengan indah arsitektur, menjadikan Cartagena salah satu situs warisan dunia UNESCO (Mei, 2019). They are kolonial, balkon, arsitektur, and situs derived from English words colonial, balcony, architecture, and site. According to Pedoman Umum Ejaan Bahasa Indonesia, all of them go through phonological adaptation, with some phonemes changing. Because a phoneme is the smallest unit of sound in a language, it is the only unit of sound that has a function indicated by a letter (Muslich, 2008). Because a change in orthography system leads to a change in pronunciation, borrowing words into Indonesian at least adapted to the phonological system of Indonesian.

Moreover, the word situs is adapted from an English word, site. Long before today in the era of Ejaan Van Ophuijsen and Soewandi, it was pronounced as sitoes. According to Carr (1958), the uniquely Dutch vowel oe has been replaced by $u$, and Indonesian has undergone two orthographic alterations that show the urgency for freedom. For example, data was discovered in the magazine included bis and buku. It evolved from boes to bus, which was orthographically identical to the Dutch bus, and was previously modified to bis. In Indonesian, the word bus, which is also present in English, has been transformed to bis. In Dutch, the word 
boekoe refers to a book, which in English is translated as buku in Indonesian. Furthermore, English and Dutch are both proto-Indo-European languages that influenced Indonesians and their national language.

According to Sriyanto (2014), orthography (spelling system) is related to grammar that incorporates letters and arranges those characters into words or sentences, which includes absorption and punctuation. The absorption system is strongly linked to the spelling system. Sriyanto (2014) claims that Ejaan Van Ophuijsen, which was legislated in 1901, was referred to long before PUEBI in 1928. Then, in 1947, a new spelling system called Ejaan Soewandi was introduced. There was an actual spelling system called Ejaan Yang Disempurnakan (EYD) in 1972, during the rule of Soeharto. This EYD is now known as Pedoman Umum Ejaan Bahasa Indonesia (PUEBI), which was previously known as EYD.

Next, in the sentence "Saya belum pernah menemukan di dunia ini, kehidupan seinteraktif dan harmonisasi sosial seindah di Lasem" (Agustus, 2019), the phrase harmonisasi sosial is derived from the English term social harmonization, which is a noun phrase with a pattern that matches the Indonesian grammatical system. Muslich (2008), with relation to suffixes in borrowing, claims that suffixes of foreign words are borrowed as a whole. This strategy can also be used to borrow a person's, place's, or institution's name.

\section{Translation}

Translation is a strategy in which the user takes a synonym in the recipient language for a new foreign word. This strategy attempts to develop new lexicons for the recipient language by incorporating concepts from other languages that do not use foreign terms. According to the findings, translation strategy was used to borrow two words and one phrase. The following are some instances of sentencebased examples.

In the sentence Jangan lewatkan swafoto di spot-spot cantik dan unik yang telah disediakan (Agustus, 2019), selfie is the English translation of the word swafoto. Because the translation strategy used to locate similar meaning to the target language, there is no need to use any foreign terms when translating this word. Selfie is a word that signifies "selfie" in English.

Furthermore, in the sentence Manager Humas Grand Candi, Azkar Rizal Muhammad menyebutkan, salah satu promo menarik untuk kalangan muda, yakni Weekend Rate dengan harga Rp 655.000 Nett/ Room/ Night untuk deluxe room kapasitas 2 orang (Agustus, 2019), two processes take place. First, the word humas was abbreviated when it was shortened from hubungan masyarakat by morphological process. Second, hubungan masyarakat, or public relations in English, is abbreviated as PR. According to Moehkardi (2019), abbreviation of borrowing is a branch of acronym that adds in this acronym, new lexeme consists of the first phoneme or grapheme of the source words, although it can sometimes be pronouned as a word, not only takes the initial sounds but sometimes consonant and vowel in the next first.

Next, in the sentence Penandatanganan nota kesepahaman antara Traveloka dan Japan Railway Company, dilakukan di Jakarta (Juli, 2019), the phrase nota kesepahaman is translated from an English phrase memorandum of understanding. There is no need to balance one-on-one form when translating foreign terms into Indonesian. The most crucial thing is to discover a synonym that expresses it in Indonesian using the same reference. 


\section{Creation}

Creation is a strategy in which users take the basic concept of a foreign language and applies it to their own language, resulting in the creation of the closest feature between the two languages. With translation strategy, it is almost the same. According to the findings, there were three phrases that used the creation strategy. Because the creation strategy is to create one foreign term by identifying its underlying concept in two or more Indonesian words, there was no borrowing in the form of a word. It is defined as a phrase in this definition. The following is a sentence-based example.

In the sentences Brebes ternyata punya hutan bakau yang sebagian sengaja difungsikan untuk kepentingan wisata (Agustus, 2019), the phrase hutan bakau is derived from the English word mangrove. It was originally used to establish basic concepts by determining the closest aspect between donor and recipient languages. The closest element of both languages is that they refer to the same topic in different ways, such as orthography systems with distinct names. According to Sridhar (1988), creation is an indigenization method derived from original sources that tries to make the new language understandable to the general public of the recipient language.

In the sentence Untuk retribusi, dipasang tarif yang berbeda bagi turis local, turis mancanegara, dan pemandu wisata (Juni, 2019), pemandu wisata is a guide written in English. According to Mihalicek and Wilson (2011), no two languages are identical, especially those belonging to separate families of languages. It means that, despite having the same meaning, different languages around the world have different forms. Furthermore, several languages are derived from many families. A word guide, for example, in the Cambridge online dictionary means a book that provides people with the most important information on specific subjects, something that assists people in forming an opinion or making a decision about something else, a person who has the job of showing people around an area or route as visitors, and a person or thing that influences people in what they do or think. It is known in Indonesian as pemandu wisata, which refers to a person who escorts tourists to show them places along their tourism itinerary. In English, it can have a variety of meanings. Absorption occurs when a language is used in communications. Susetyo (2016) investigated the types and strategies of English borrowing words in Indonesian and published on the Opini page of Kompas newspaper.

\section{Equivalences among Form, Pronunciation, and Meaning}

There are two types of English borrowing words in Indonesian, based on equivalences between forms, pronunciation, and meaning of English borrowing in Indonesian: word and phrase. There were 208 words and 21 phrases that changed their forms from the entire data of 250 borrowing items. In addition, 21 terms were discovered that did not modify their forms. It means they have the same forms as each other, but with different patterns. There were 229 words and 21 phrases that had meaning. In Indonesian, there was no form of English borrowing that changed the meaning. In terms of pronunciation, there were 169 words in Indonesian that changed their pronunciation and 1 word that did not. Furthermore, 21 sentences had their pronunciations modified. The following table gives more specific information. 
Table 4.

Frequencies of Equivalences among Form, Pronunciation, and Meaning of English Borrowing Words in Indonesian

\begin{tabular}{lccccccc}
\hline No. & $\begin{array}{c}\text { Type of } \\
\text { Borrowing }\end{array}$ & \multicolumn{2}{c}{ Form } & \multicolumn{2}{c}{ Pronunciation } & \multicolumn{2}{c}{ Meaning } \\
Change & $\begin{array}{c}\text { No } \\
\text { change }\end{array}$ & Change & No Change & Change & No change \\
1 & Word & 208 & 21 & 228 & 1 & 0 & 229 \\
2 & Phrase & 21 & 0 & 21 & 0 & 0 & 21 \\
& Total & $\mathbf{2 2 9}$ & $\mathbf{2 1}$ & $\mathbf{2 4 9}$ & $\mathbf{1}$ & $\mathbf{0}$ & $\mathbf{2 5 0}$ \\
\hline
\end{tabular}

Further discussions about forms of English borrowing words in Indonesian, strategies, and equivalences between form, pronunciation, and examples of data provided in table 5 presented below are based on those findings. For annotation, -------- $=$ same sentence/ source, $\sqrt{ }=$ change, $-=$ no change.

Table 5.

Examples of data related to equivalences among form, pronunciation, and meaning

\begin{tabular}{|c|c|c|c|c|c|}
\hline No. & $\begin{array}{l}\text { Data } \\
\text { (DL) }\end{array}$ & $\begin{array}{l}\text { Data } \\
(\mathbf{R L})\end{array}$ & $\begin{array}{c}\text { Change/ no } \\
\text { change } \\
\text { whether form, } \\
\text { pronunciation } \\
\text { or meaning }\end{array}$ & Sentences & Sources \\
\hline 1. & Swafoto & Selfie & $\sqrt{ }$ & $\begin{array}{l}\text { Jangan lewatkan swafoto di } \\
\text { spot-spot cantik dan unik yang } \\
\text { telah disediakan. }\end{array}$ & $\begin{array}{l}\text { Agustus, } \\
2019\end{array}$ \\
\hline 2. & Spot & Spot & - & -------------------' & ------------ \\
\hline 3. & Film & Film & - & $\begin{array}{l}\text { Film sangat berperan sebagai } \\
\text { media propaganda dan promosi, } \\
\text { apalagi untuk pariwisata. }\end{array}$ & Mei, 2019 \\
\hline 4. & $\begin{array}{l}\text { Media } \\
\text { propaganda }\end{array}$ & $\begin{array}{l}\text { Propagan } \\
\text { da media }\end{array}$ & $\sqrt{ }$ & ----- & ------------- \\
\hline 5. & Kreatif & Creative & - & $\begin{array}{l}\text { Sejarah Berlin yang kelam, jiwa } \\
\text { kreatif yang sekarang bebas, } \\
\text { arsitektur bangunan yang indah, } \\
\text { dan juga demonstrasi } \\
\text { pembuatan bir, membuat kota itu } \\
\text { menjadi salah satu sasaran } \\
\text { kunjungan traveler perempuan }\end{array}$ & ------------- \\
\hline 6. & Arsitektur & $\begin{array}{l}\text { Architect } \\
\text { ure }\end{array}$ & - & & ------------- \\
\hline 7. & Demonstrasi & $\begin{array}{l}\text { Demonstr } \\
\text { ation }\end{array}$ & - & & ------------- \\
\hline 8. & Bir & Beer & - & -------------------- & ------------- \\
\hline
\end{tabular}


In the sentence Jangan lewatkan swafoto di spot-spot cantik dan unik yang telah disediakan (Agustus, 2019), in terms of form, the word swafoto means "selfie" in English. Translation is a strategy for finding a similar meaning of a foreign word in one's own language without actually utilizing the foreign term. As a result, the word forms in the two languages differ, and it changes to Indonesian. The Indonesian word spot-spot is a reduplication of the English fundamental word spot. Both English and Indonesian have the same pronunciation.

In the sentence Film sangat berperan sebagai media propaganda dan promosi, apalagi untuk pariwisata (Mei, 2019), there are film and media propaganda. Film is pronounced /film/ in English. It means that it adapts its pronunciation to the Indonesian language of the recipient. Meanwhile, the phrase "media propaganda" is derived from the English words "media" and "propaganda," which do not serve as grammatical subjects or verbs. However, the word "media" is pronounced as /'mi:.di.ə/, while the term propaganda is pronounced /,prop.ə'gæn.də/ in English. It demonstrates that the English and Indonesian pronunciations of the phrase media propaganda are different.

Furthermore, in the sentence Sejarah Berlin yang kelam, jiwa kreatif yang sekarang bebas, arsitektur bangunan yang indah, dan juga demonstrasi pembuatan bir, membuat kota itu menjadi salah satu sasaran kunjungan traveler perempuan (Mei, 2019), there are four items of English borrowing words in Indonesian. They are kreatif, arsitektur, demonstrasi, and bir. The word kreatif is adapted from the English adjective, creative. It means producing uncommon ideas in English. It means "ability to produce something" in Indonesian. The word arsitektur is adapted from the English noun, architecture. In English, it refers to the art of designing and constructing buildings. In Indonesian, it refers to the study of architecture, as well as the art of designing and constructing buildings. Demonstrasi is a term derived from the English word demonstration. It means "how something works" in English. It literally means "showing up to do anything" in Indonesian. The word bir is derived from the English word beer. It is an alcoholic beverage created from hops and grains in English. In Indonesian, it refers to a fermented alcoholic beverage. Both Indonesian and English have equivalent meanings.

Linguistic sign is arbitrary and has a good relationship with significant and signifier, which are sound image and concept, respectively. According to Araki (2016), a sign is the result of a mental collaboration between two very distinct things: a notion or abstract idea and a sound image that is associated with that concept. It is also the sound's mental imprint. However, according to Duan (2012), a notion is not the same as an object, even if they are closely related. People have an idea in their heads, which they refer to as a notion. Meanwhile, the object refers to the reflection of something in their minds. In other words, the link between signals and meaning is arbitrary. Before and after borrowing language, concept and sound picture have an impact on the words. A word like culinary, for example, serves as an idea or meaning whose sound sequence serves as a signal. In English, it is associated with cooking or the kitchen, while in Indonesian, it has been modified to kuliner. According to KBBI website (2019), it has to do with cooking. It means that those languages have a similar concept, and therefore the same idea might be conveyed by a different sound sequence or even a different language family. 
Words derived from English as donor language, whether they alter or not according to orthography system, phonological system, or semantic meaning as semantic to Indonesian as recipient language, have equivalence between form, meaning, and pronunciation in English and Indonesian. Speakers can import not only form and meaning, but also phonemic shape or pronunciation and this is more or less a substitute with local phonemes (Haugen, 1950).

\section{CONCLUSION}

Based on the previous discussion, English borrowing in Indonesian can be separated into two categories. It is a matter of words and phrases. The most common type was word. In addition, there are four ways for assimilations of English borrowing words into Indonesian. Adoption strategy has 21 words and 0 phrases in common with other people. Because the strategy's concept is to turn one foreign word into two or more Indonesian words, no words were found using this strategy. Adaptation was the most commonly used strategy. It demonstrates that Indonesians prefer to adapt English rather than adopt it. However, this research discovered partial and full adoption through adoption strategy. Words and phrases that have assimilated to Indonesian, found in KBBI, have the same form and meaning but different pronunciation, and the same pronunciation and meaning but different form. Furthermore, they have the same meaning but differ in form and pronunciation, or they share the same form, pronunciation, and overall meaning. Hopefully, this research will benefit the modernization of Indonesian lexicons, as well as the introduction of BIPA learners and other foreigners to the lexicons. It is expected to provide a wealth of information to people who enjoy reading linguistics. It is also open to criticism and recommendations for improvement.

\section{REFERENCES}

Aarts, B. \& McMahon, A. (Eds). (2006). The Handbook of English Linguistics. Victoria: Blackwell Publishing

Araki, N. (2016). Saussure and Chomsky. Langue and I-language. Entornos, 29(2), 285-296.

Auer, P. (2014). Language Mixing and Language Fusion: When Bilingual Talk Becomes Monolingual. in J. Besters-Dilger, C. Dermarkar, S. Pfänder \& A. Rabus (Ed.), Congruence in Contact-Induced Language Change (pp. 294334). Berlin, Boston: De Gruyter. https://doi.org/10.1515/9783110338454.294

Carr, D. (1958). Some Problems Arising from Linguistic Eleutheromania. The Journal of Asian Studies, 17(2), 207-214.

Cholsy, H., Wijana, I. D. P., Nadar, F. X., \& Udasmoro, W. (2014). The Status of French Loanwords in the Indonesian Language. Humaniora, 26(3), 303-314. DOI: 10.22146/jh.6189

Darheni, N. (2009). Penyerapan Leksikon Asing dalam Bidang Otomotif ke dalam Bahasa Indonesia: Tinjauan secara Morfologis dan Fonologis. Jurnal Sosioteknologi, 8(17), 646-666.

Duan, M. (2012). On The Arbitrary Nature of Linguistic Sign. Theory and Practice in Language Studies, 2(1), 54-59. DOI: 10.4304/tpls.2.1.54-59.

Frederick, W. H. \& Worden R. L. (Eds). (2017). Indonesia: A Country Study (6th ed). Washington: Autenticated U.S. Government Information 
Haugen, E. (1950). Analysis of Linguistic Borrowing. Language 26(2), 210-231. DOI: $10.2307 / 410058$

Helleland, B. (2012). Place Names and Identities. Oslo Studies in Language, 4(2), 96-116. DOI: https://doi.org/10.5617/osla.313

Khaled, B. (2013). Aspects of Code Switching, Code Mixing, and Borrowing Used by The Older Generations in Tiaret (Master's thesis, University of Oran). Algeria: University of Oran.

Khan, S. A. (2016). The Distinction Between Term And Word: A Translator And Interpreter Problem and The Role of Teaching Terminology. ProcediaSocial and Behavioural Sciences, 232, 696-704. DOI: 10.1016/j.sbspro.10.095

Lauder, A. (2008). The Status and Function of English in Indonesia: A Review of Key Factors. Makara Human Behavior Studies in Asia, 12(1), 9-20.

Marmiéné, A. (2015). The Use Lexical Borrowing and Their Lithuanian Equivalents in the Computer-Mediated Environment in Students's Speech. Santalka: Filologija, Edukologija/Coactivity: Philology, Educology, 23(2), 119-126. DOI: 10.3846/cpe.2015.276.

Meridhita, M. (2012). Perubahan Morfemis Kata Benda Pinjaman Bahasa Rusia dari Bahasa Perancis. (Skripsi, Universitas Indonesia). Depok: Universitas Indonesia

Mihalicek, V. \& Wilson, C. (2011). Language Files: Materials for an Introduction to Language and Linguistics. Columbuss: Ohio State University Press.

Moeliono, A. (1985). Pengembangan dan Pembinaan Bahasa. Jakarta: Djembatan.

Moehkardi, R. R. D. (2016). Pattern and Meaning of English Word Through Word Formation Processes of Acronym, Clipping, Compound, and Blending Found in Internet-Based Media. Humaniora, 28(3), 342-338.

Moehkardi R. R. D. (2019). English Blend in Indonesian Context: Their Formation Processes and Meanings. Humaniora, 31(1), 21-32.

Mulyaningsih, I. (2017). Sikap Mahasiswa Terhadap Bahasa Indonesia. Indonesian Language Education and Literature, 3(1), 79-87.

Murtisari, E. T. \& Mali, Y. C. G. (2017). Impact of English on the Indonesian Language and Culture: High School Students' Perceptions. Research Journal Studies About Language, 30, 90-104. DOI: 10.5755/j01.sal.0.30.17570.

Muslich, M. (2008). Tata Bentuk Bahasa Indonesia: Kajian ke Arah Tata Bahasa Deskriptif. Jakarta: Bumi Aksara.

Nian, O. S., Jubilado, R. C., Dumaniq, F. P., \& Mohd Noor, A. H. (2012). A Contrastive Analysis of the Reduplication Process in Bahasa Melayu and Japanese. Polyglossia: The Asia-Pacific's Voice in Language and Language Teaching, 22, 1-5.

Rahman, F. (2018). Kuliner sebagai Identitas Keindonesiaan. Jurnal Sejarah, 2(1), 43-63. DOI: $10.26639 /$ js.v\% vi\%i.118

Ramadhita, R. (2013). Strategi Pengembangan Fasilitas Guna Meningkatkan Minat Wisatawan di Obyek Wisata Talaga Herang Kabupaten Majalengka. (Master's Thesis, ch. 1, Universitas Pendidikan Indonesia, 2013). Bandung: Universitas Pendidikan Indonesia. 


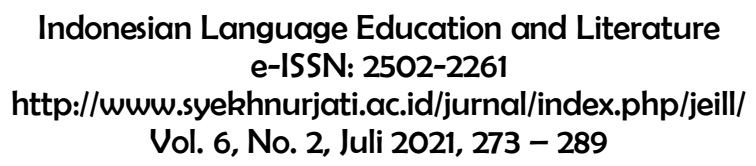

Samuel, J. (2008). Kasus Ajaib Bahasa Indonesia? Pemodernan Kosakata dan Politik Peristilahan. Jakarta: Gramedia.

Sridhar, S. N. (1988). Language Modernization: Structural and Sociolinguistics Aspect. Euskara Biltzara Congrezo de la Lengua Vasca, 1(1), 351-360.

Sriyanto, S. (2014). Seri Penyuluhan Bahasa Indonesia: Ejaan. Jakarta: Kemendikbud.

Sudaryanto, S. (2015). Metode dan Aneka Teknik Analisis Bahasa. Yogyakarta: Sanata Dharma University Press.

Supeni, S. \& Fauziah, A. (2018). English Loanwords on Indonesian Health Article in Online News Pages. Journal of English Language and Literature, 3(2), 20-34. DOI: 10.37110/jell.v3i2.54

Susetyo, A. M. (2016). Penggunaan Kata dan Istilah Bahasa Inggris pada Rubrik Opini Surat Kabar Kompas. Jurnal Belajar Bahasa, 1(1), 11-24.

Tabiati, S. E., \& Yannuar, N. (2012). The Borrowed Words in Jakarta Post Newspaper: A Case of Varieties of English. Englishes for Communication and Interaction in Classroom and Beyond, 1-15.

Tadmor, U., Haspelmath, M., \& Taylor, B. (2010). Borrowability and the Notion of Basic Vocabulary. Diachronica, 27(2), 226-246. DOI: https://doi.org/10.1075/dia.27.2.04tad

Valtonen, T. (2017). Place-Name Loaning Patterns as Cultural Survival Strategies in Same Context. Journal of Northern Studies, 11(2), 53-70.

Winarto, A. B. (2013). Borrowing Words in Newspaper Seputar Indonesia Desember 2009. Buletin Al-Turas, 19(1), 119-134.

Wohlgemuth, J. (2009). A Typology of Verbal Borrowings. Berlin, New York: De Gruyter Mouton. https://doi.org/10.1515/9783110219340

https://dictionary.cambridge.org/online/

https://kbbi.kemdikbud.go.id/ 